\title{
THE TOMB OF SETI I (KV17) IN THE FLORENCE EGYPTIAN MUSEUM. INTEGRATED NON-INVASIVE METHODS FOR DOCUMENTATION, MATERIAL HISTORY AND DIAGNOSTICS.
}

\author{
M. Coppola ${ }^{\text {a }}$, S. Bracci ${ }^{\text {b }}$, E. Cantisani ${ }^{\text {b }}$, D. Magrini ${ }^{\text {b }}$ \\ a DIDA, Dept. of Architecture, University of Florence, Italy - michele.coppola@unifi.it \\ b ICVBC - CNR, Florence, Italy - bracci@icvbc.cnr.it, cantisani@icvbc.cnr.it, magrini@icvbc.cnr.it
}

KEY WORDS: Seti I, Egyptian architecture, Imaging, KV17, Egyptian Blue, Diagnostics, Florence Egyptian Museum

\begin{abstract}
:
The tomb of Seti I (KV17) is a magnificent example of New Kingdom funerary architecture, among the longest tombs in the Valley of the Kings. As part of a collaboration between the Egyptian Museum in Florence, the University of Florence and CNR, a survey project was launched, with non-invasive methods, on the fragments from the Seti I tomb, in Florence, coming from a gate jamb connecting the chamber F to the corridor G, taken by the franco-tuscan expedition in 1829. The primary goal is to achieve the best level of documentation, knowledge of the material history and conservation assessment. Preliminary results allowed to focus some steps of the history of this fragment, from its realization to the present. The digital documentation created an excellent support for the mapping and management of the collected information. Even if still on a preliminary phase, this study shows how the combination of imaging and spectroscopic techniques allowed the characterization of many materials and the mapping of their distribution on the surface. Several original pigments have been identified as well as many anomalies due to subsequent interventions.
\end{abstract}

\section{INTRODUCTION}

Conservation, knowledge, documentation and data-sharing are more and more essential in contemporary research on pharaonic architecture. The architectural fragments in museums around the world are a parallel resource in this field of study and the potential of the current investigation techniques generates new opportunities and needs of methodological correctness. The systematic and thorough study of these artifacts, could have a substantial raise, especially in Italy. The LARC laboratory of the University of Florence has started a research project in order to contribute to the study and conservation of in-situ pharaonic architecture, through the study of the heritage "outside" Egypt. This research field is wide and rich in perspectives. The investigation in museum offers several advantages over an archaeological site: the direct and easy access of objects, the use of equipment which cannot be used outdoors and an increased need for non-invasive techniques because of the restriction of the materials sampling for laboratory tests. The first part of this research is developed in collaboration between the Department of Architecture of the University of Florence, the Florence Egyptian Museum and the ICVBC-CNR of Florence. Integrated methodologies for documentation and non-invasive investigation were applied to a fragment of a wall of Seti I tomb (KV17), kept in the Florence Egyptian Museum. This represents just a starting point for the identification of the further developments of the research. The primary goal is to achieve the best level of knowledge and documentation of this artefact which really needs an appropriate level of investigation after many years. The evaluation of the quality of data allows to define the extent of any laboratory analysis. In another way, the verification of the potential applications of this interdisciplinary approach, can bring together results in an integrated protocol, for the survey of similar artifacts in the museum and elswhere.

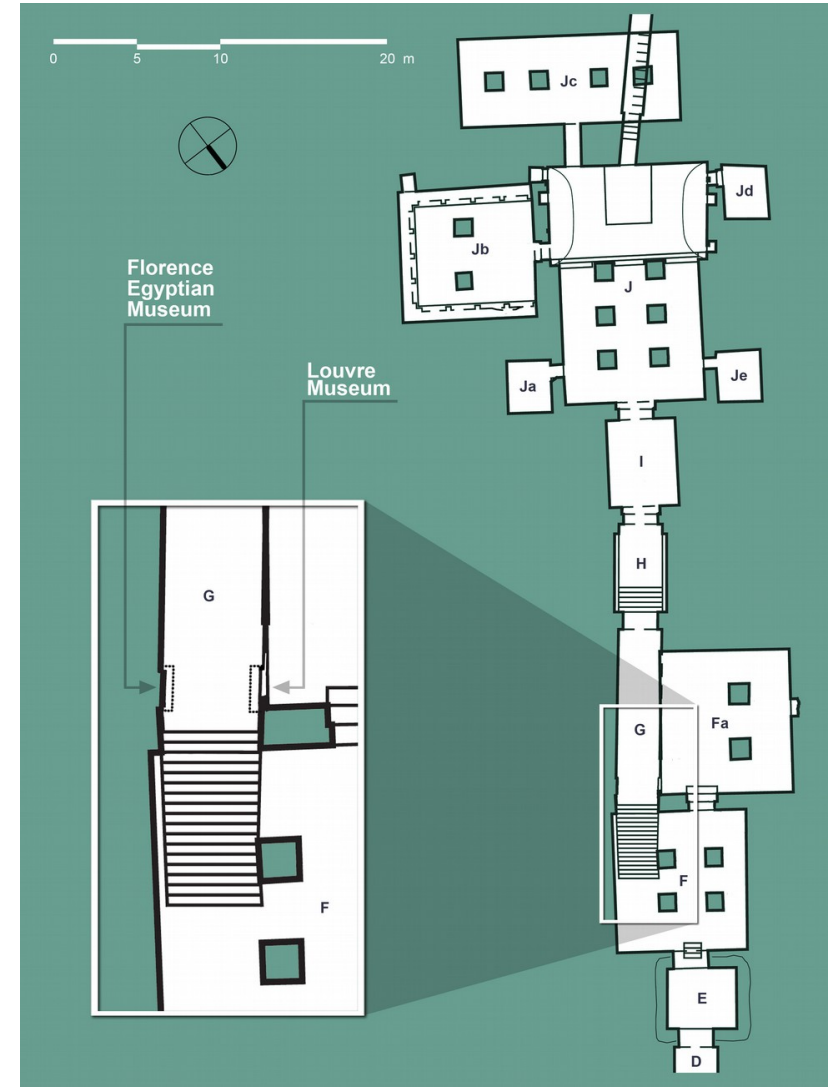

Figure 1. Plan of the tomb KV17 with the indication of the removed jambs of the gate G. (elaboration from K. Weeks, The Theban Mapping Project, sheet 35/72). 


\section{THE TOMB OF SETI I IN FLORENCE}

\subsection{Technologies and materials of a royal decoration}

Seti I (1324-1279 BC) was the first important king of the 19th dynasty. He worked to restore the general order in the country and reactivate the ancient cults. He promoted the construction of many monumental complexes which mark an important highlight in the Egyptian art and technique history (Hornung, 1991). His tomb (KV17), one of the largest (about $140 \mathrm{~m}$ long) in the Valley of the Kings (Wadi el-Muluk), entirely painted with polychrome reliefs of extraordinary quality, is probably the greatest known example of funerary architecture of the New Kingdom (Figure 1). Ippolito Rosellini said: "la gran sala del sarcofago [...] sembra piuttosto un'opera d'incantesimo che di arte" (Gabrieli 1925, p. 130). It is an important material archive for the knowledge of the best architectural decoration techniques of that time. After cutting of the volumes in the rock, the surfaces were finished, to receive the pictorial decoration. Abnormalities in the rock made necessary a prior preparation. Cracks or gaps left by fossils and inclusions were filled with a gypsum mortar, which, for the decoration in relief, was of greater thickness, to be carved after hardening (Beni Hasan, El$\mathrm{Khab}$, etc.). The major gaps were integrated with stone blocks shaped to correctly fit in. As evidenced by unfinished monuments (some tombs of Thebes, the Amenophi IV tomb and some other monuments of Tell El Amarna, etc) the figures were first sketched in red. The final outlines were then traced in black by another artist, to create the final and correct guide for the sculptor. A coating thin gypsum-based preparatory layer was given to ensure a homogeneous background from the chromatic and absorption point of view. The high technical quality of the tombs of Thebes, also due to the excellent quality of the rock (a fine, homogenous and compact limestone) ensured a good preservation of the paintings, observed by many travellers of the past. The main in-situ causes of degradation of these architectures are infiltrations of water, with the consequent transport of salts, detachment and fall of fragments but also cracks due to the mechanics of the rock layers. Their reuse as dwellings, barns, hermitages, warehouses can have caused different transformations over the centuries, from carbon black deposits of lamps and fireplaces, till the cuts in the rock walls. Like many other royal tombs, despite the precautions of the builders to hide the access (for example by closing the shaft E), the tomb of Seti I was the subject of numerous thefts already in Pharaonic times. The mummy of the king was among those transferred in the 10th century BC, in the hiding place of Deir el Bahari (TT320). The objects found by Belzoni are remnants of a vaste and rich range disappeared for centuries. (Donadoni, 1965).

\subsection{From Belzoni's discovery to Florence}

Gian Battista Belzoni discovered the tomb in 1817, and he immediately realized its importance, describing it as "the principal, the most perfect and splendid monument in that country" (Belzoni 1820, p. IX). He did make drawings and wax casts of many decorations and staged an exhibition in England, in 1821. The conservation conditions were good and many of the early visitors said that the colors were as fresh as if the painters had just finished their work. The plates attached to his publication document some of the removed reliefs, still in place (Figure 2). The opening, though, began a long degenerative process, since the following year, when a flood caused the fall of fragments from walls and ceilings. The Franco-Tuscan expedition 182829, led by Jean François Champollion and Ippolito Rosellini, marked an important step in the history of this monument. The activities of the mission provided a wide documentation but mostly the collection of objects. During the study of the Seti I tomb, both the scholars remarked the freshness of its paintings but also their increasing decay. In a letter to ChampollionFigeac of may $29^{\text {th }} 1829$, Champollion wrote: “[...] Dans la vallée proprement dite de Biban el-Molouk, nous avons admiré, comme tous les voyageurs qui nous ont précédés, l'étonnante fraicheur des peintures et la finesse des sculptures du tombeau de Ménéphtah Ier, [...] Mais cette belle catacombe dépérit chaque jour. Les piliers se fendent et se délitent; les plafonds tombent en éclats, et la peinture s'enlève en écailles." (Hartleben 1909, p. 299). In September of the same year, they decided to remove some reliefs portions that, with thousands of other artifacts, were sent to France and Tuscany.

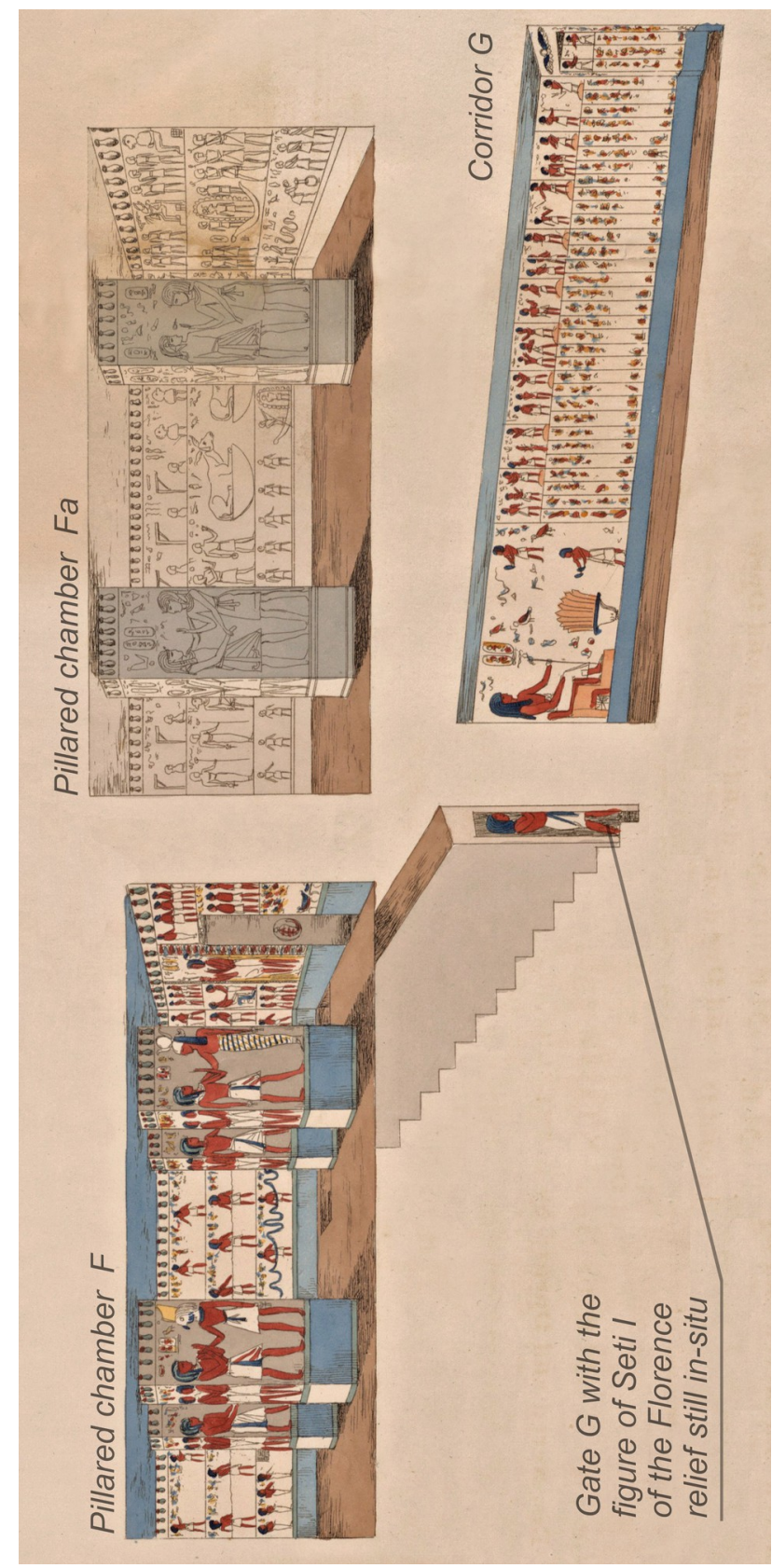

Figure 2. Section of the tomb published by Belzoni. The jambs of the gate $\mathrm{G}$ are still in place. The relief kept in Florence is partly visible. (Elaboration from Belzoni, 1820, pl. 40). 
The gate G (H $2.7 \mathrm{~m}, \mathrm{~L} 2.09 \mathrm{~m}, \mathrm{~W} 1.05 \mathrm{~m})$ was mainly involved in these operations. It marks the transition from the upper to the lower section of the tomb and connects the pillared chamber $(\mathrm{F})$ to the corridor $\mathrm{G}$, just following a staircase (Figure 1). Here the rock was shaped to create the lintel and the jambs of a monumental passage. The same scene is carved on both the jambs in a specular way, described and drawn from Belzoni (Belzoni, 1820 , p. 244, pl. 18), in which the goddess Hathor welcomes the King and offers him her necklace. The jambs were removed in 1829 by Champollion and Rosellini, who published the drawings (Champollion, 1845, Tome III, pl. CCLI; Rosellini, 1834, pl. LVIII). The fragment of Florence comes from the left jamb (SE) while its opposite at Louvre (n. B7) on the right side $(\mathrm{NW})$. Their width $(1.05 \mathrm{~m})$ indicates that they have been removed for the entire depth of the gate.

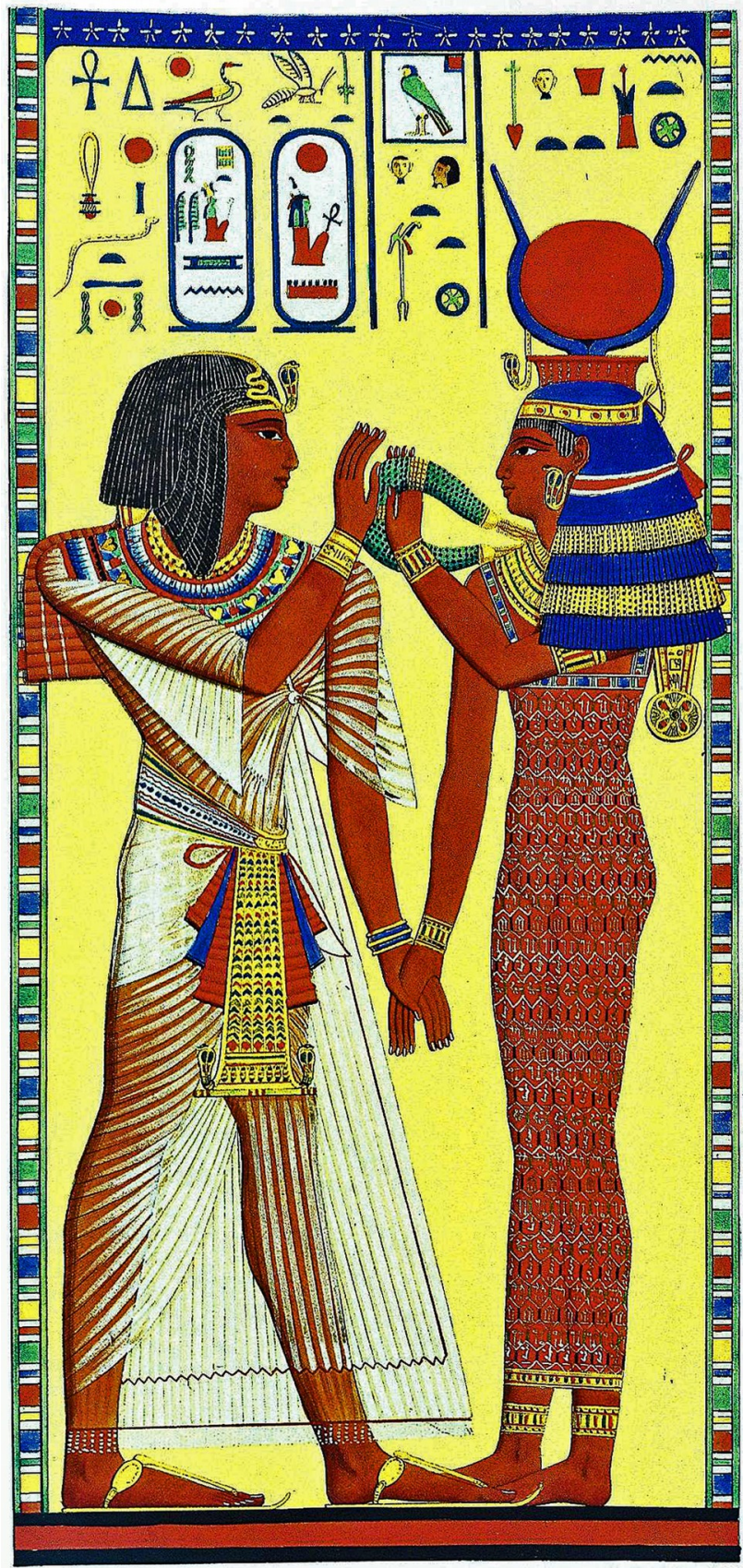

Figure 3. The drawing taken from Ricci, before the cutting and published by Rosellini. (Rosellini, 1834, pl. LVIII).

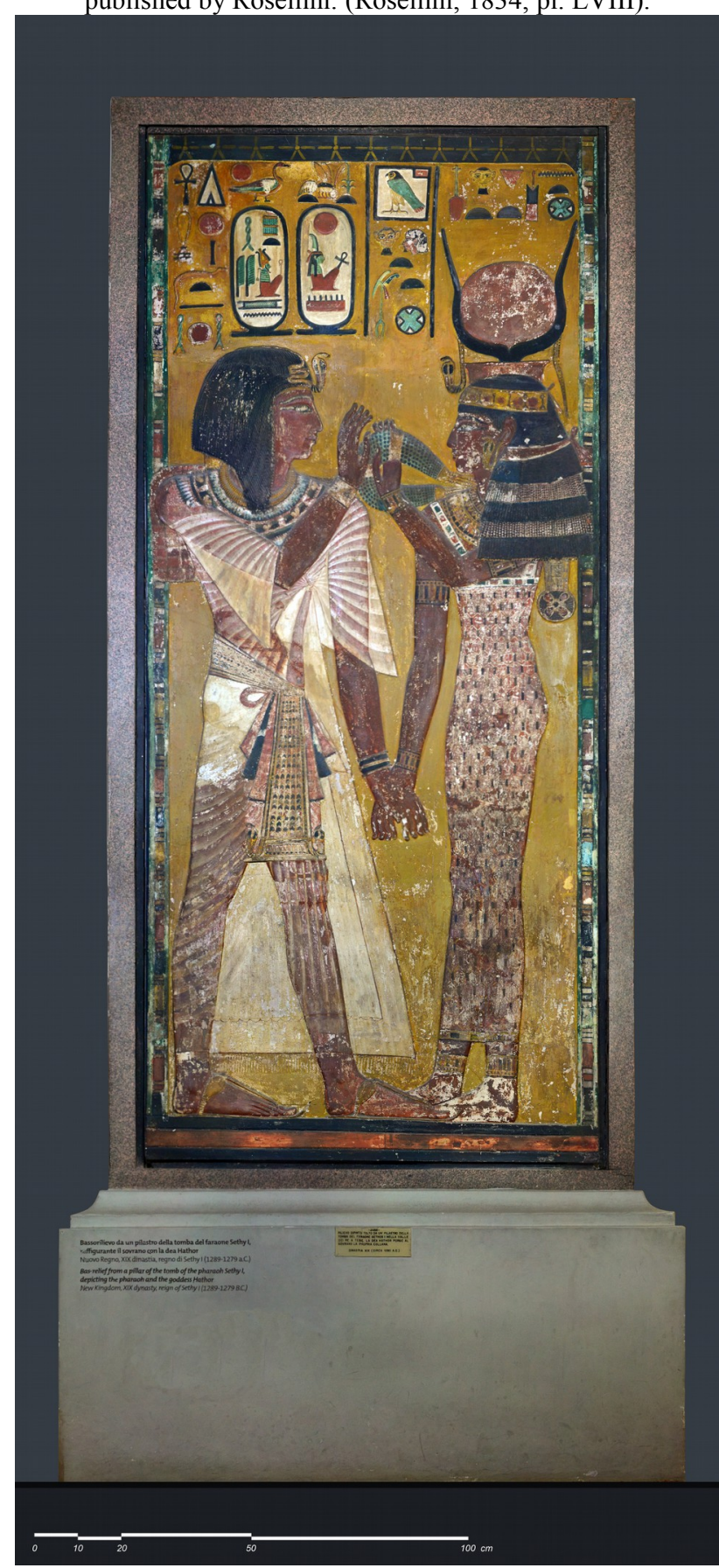

Figure 4. Elevation taken from the digital 3D survey of the wall fragment in its current condition (2017).

In his final publication, Ippolito Rosellini describes the operations that he carried out: [...] Questo quadro, le di cui figure hanno presso a poco le dimensioni del vero, trovavasi sopra il rilievo di un finto pilastro, che potei far segare $e$ trasportare in cassa [...] $i$ colori che nelle perpetue tenebre della tomba erano freschi e vivaci [...] assai cambiarono pel trasporto, pel ristauro e più pel soggiorno nel nostro umido clima, divennero foschi e anneriti quali ora si mostrano. [...] (Rosellini, 1844, p. 356-358). The plate number LVIII of the publication represents the removed jamb, drawn by Ricci, with the indication of all the colors as they were visible at the 
moment of the survey, just before the cut (Figure 3). The objects collected by Rosellini were exhibited in 1831 at the Accademia of S. Caterina, soon joined by the first Grand Ducal collection of Egyptian antiquities (the Nizzoli collection), until then kept in a room of the Uffizi gallery, near the tribune. The jamb cut from the tomb of Seti I was still travelling at that time and a scale reproduction was exhibited in its place. It arrived at Florence later, in fragments and it was reassembled and restored to be exhibited to the public (Rosellini, 1830, p. 18). Of course the intervention must have included the filling of gaps and junctions. Consequently many painting integration were probably necessary to camouflage the fillings and to revive the strongly altered colors, as Ippolito Rosellini remarked immediately after the arrival in Italy. The collection remained abandoned until 1852, then it was transferred by Michele Migliarini to the Cenacolo di Fuligno as a new place for the Egyptian collections (Gamurrini, 1873, p. 20). In this occasion some additional restorations may have taken place, to recover damages due to the abandonment. The connection between the parts must have been preserved.

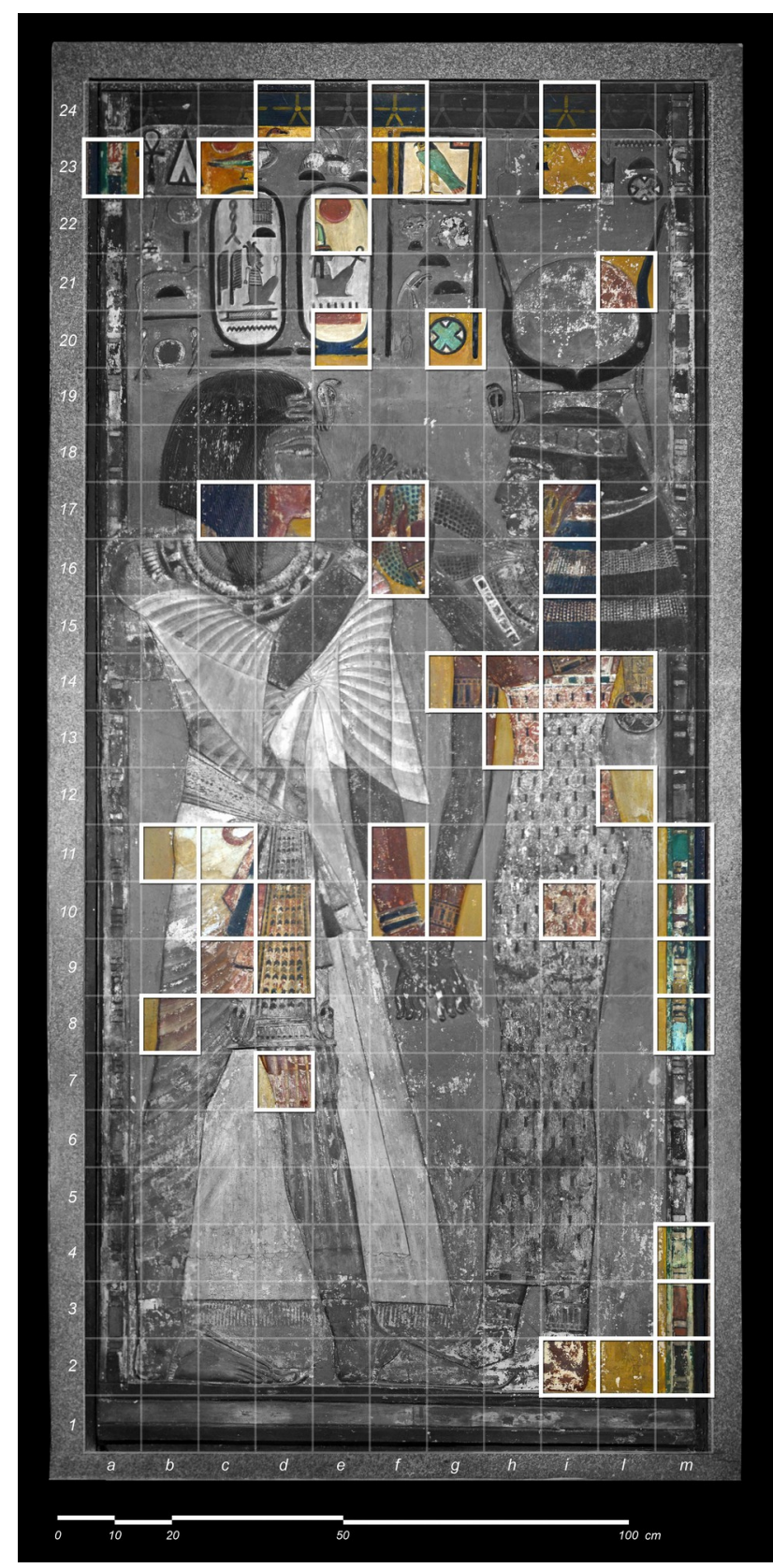

Figure 5. Sampling of the surface with the selected areas.

Since 1880 Ernesto Schiaparelli was commissioned to reorganize all the antiquities in the actual museum, in Palazzo della Crocetta. The intervention included also an egyptian-style decoration of the rooms (papyrus columns, cornices, ceilings). Following this attitude, the jamb was placed in the current position on a stone base, leaning against a central wall and surrounded by a wooden frame, decorated by a pink granite pattern, as already documented by some Alinari brothers photos of the late nineteenth century (1887-1900). 


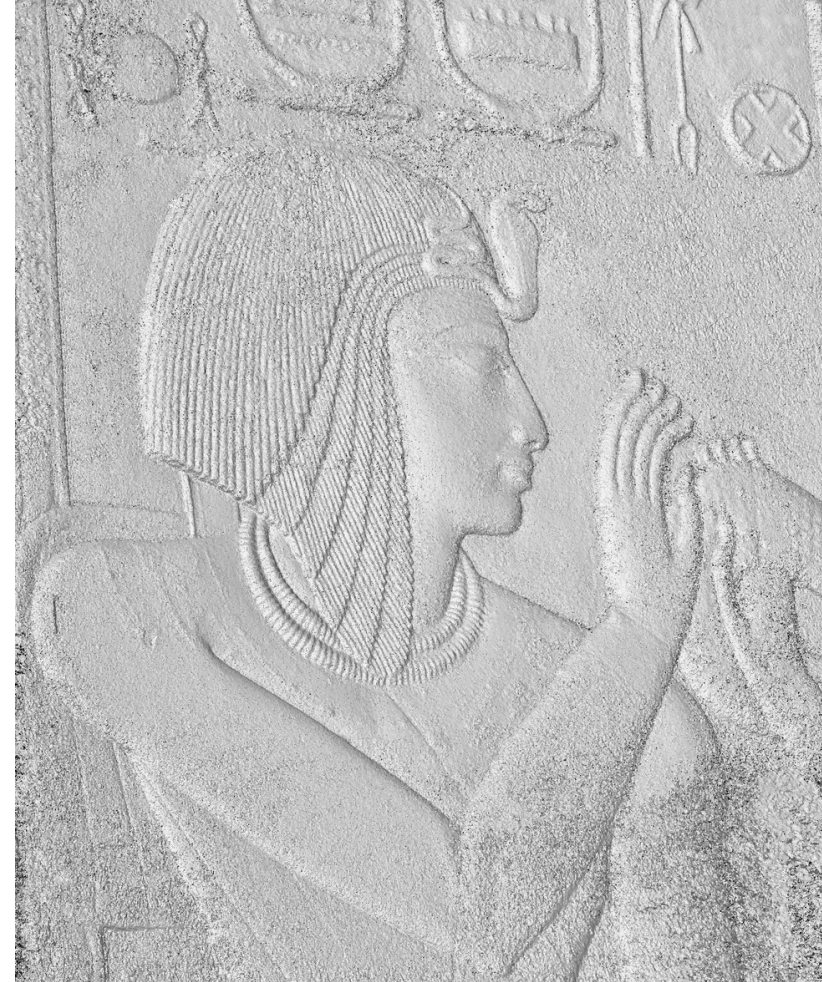

Figure 6. Detail of the dense points-cloud taken from the decorated surface, with the King Seti figure.

We are not aware of any conservation work during the transfer. In his guide of the museum Schiaparelli, who mistakenly attributed its origin from a pillar of the first room of the tomb, wrote that the relief appeared restored and repainted: "restaurato e ridipinto in parecchi punti" (Schiaparelli, 1883, p. 20). In addition, some years later, he confirms the fragmentation of the jamb and its reassembly made in the past (Schiaparelli, 1887). Talking about the skin of the goddess Hathor, he believed untrusted the red color, saying "pare che sia stato aggiunto di recente da chi restaurò questo bassorilievo." (Schiaparelli, 1887, p. 321). The goddess dark complexion, though, is quite clearly documented also by the drawing published by Belzoni in 1820, of the jamb now at the Louvre. Schiaparelli generally seems alluding to his own strangeness to further interventions. We can even think that the jamb was moved keeping together the old connections, just put on place against the wall. In a later catalogue, reference is made to the relief, saying that "it is completely restored" (Milani, 1923 , p. 115). Some green drops on the frame, the same green of some areas of the perimeter band, indicate that repainting have been performed even after the final positioning. In the outer areas there are color splashes of the faux-granite decoration of the frame, evidently painted without any protection for the relief. At the moment, any conservation works are not documented for the recent decades. There is a gap of information about restoration actions until the 70's. It seems hardly believable that additional painting integration were carried out, but we cannot exclude that at least some consolidating treatments were given on the surface. In the last 35 years no intervention was undertaken.

Other large fragments, now in the Neues Museum of Berlin, were removed from the tomb, by Karl Richard Lepsius (184245). In 1886 Gustave Lefebvre published all the decorated surfaces of the tomb (Lefebvre, 1886). The elevations representing the left wall of the corridor $\mathrm{G}$ show the gap left by the Florence relief, with some decoration left. The degradation of the paintings is widespread, in some cases accelerated by casts made by early scholars. During the twentieth century, the tomb has been studied and restored (Carter, 1903). Recently some conservation works were carried out by the American Research Centre (Jones, 2003). The general conditions of the tomb, though, remain unstable and it is currently closed to the public.

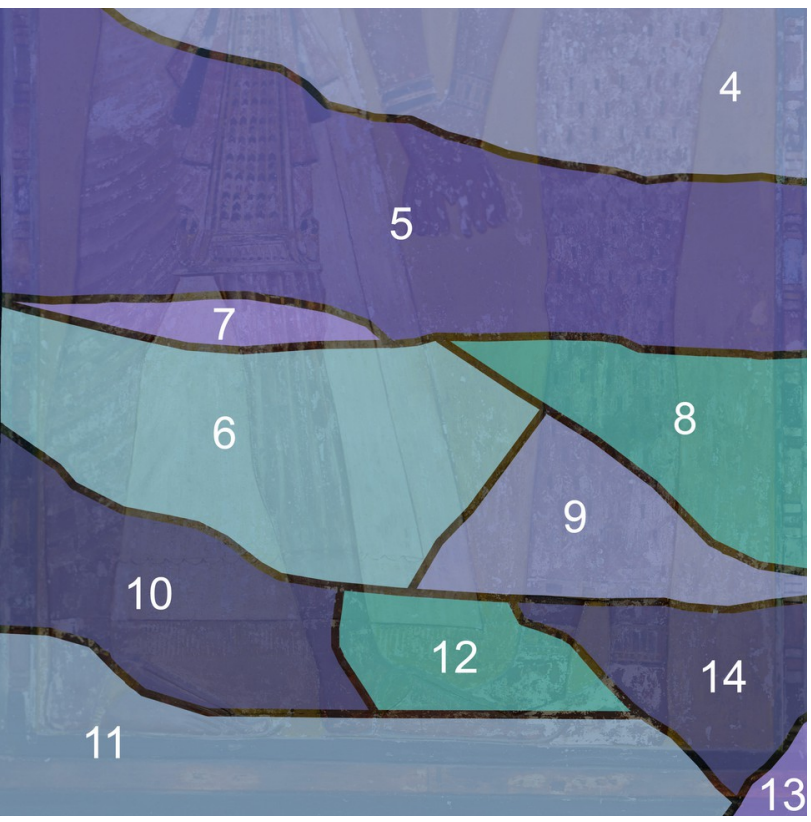

Figure 7. Mapping of the macroscopic cracks and hypothesis of the main fragments composition of the lower part.

\subsection{Subject, aims and methods of investigation}

The fragment investigated is exhibited in the room V (n. 2468). Excluding a brick integration, visible through a gap on the right side, the wooden frame hides the connection to the wall and any traces of decoration on the thickness. The painting layers are visibly altered and darkened. Repainting and surface deposits are widespread, clearly visible on integrations and along the junctions. All portions on which the blue is documented, appear almost black. This transformation cannot be immediately attributable to the systematic addition of overlapping color layers, treatments or alterations of the original pictorial material. Many green areas have been widely recolored. Gaps of the painting layer, many of which are documented since the nineteenth century, are spread especially in the lower part. In some areas, the detaching of the painting layer is in progress and should be monitored. The loss of surface layers shows their thickness and discovers the limestone rock support, upon which some finishing traces can be seen. The survey is developed according to three purposes: 1) full digital documentation; 2) reconstruction of the material history, through the study of materials and traces; 3) Diagnosis of the state of conservation and of the on-going degenerative phenomena. The first survey campaign focused on the beginning of the documentation and the selection of the imaging methods. A 3D survey with HD images photogrammetric processing software was carried out (Figures 4,6). The obtained model creates a support for the surveys planning and for data mapping and management. The surface was divided into a square mesh grid $(10 \times 10 \mathrm{~cm})$ to identify each sample area by a number and a letter. 46 sample areas were selected in this campaign, according with some 
representative parameters: color assortment, working traces, extraneous matter, repainting, decay, gaps (Figure 5). The high resolution digital photography allowed the systematic mapping and identification of the crack pattern. It suggested a preliminary composition into 14 possible blocks of the entire element. The greater fragmentation is concentrated in the lower portion, but the current information doesn $\mathrm{t}$ allow us to determine whether the scarcity of fractures in upper part is due to a better preservation of the $19^{\text {th }}$ century restorations or to a real integrity (Figure 7). Any further investigations in remote sensing could clarify these hypothesis. Each area has been documented with macro photos, with a detail photogrammetry processing. Micro photos were taken using a digital camera and a portable digital microscope allowing a detailed observation of the surface and the assessment of the state of conservation (Figure 8). The stratigraphic macroscopic reading of surface has identified the relationships between parts that are visually homogeneous, the fillings along the junctions and the pictorial integrations. It also allowed the classification of the most frequent homogeneous units.

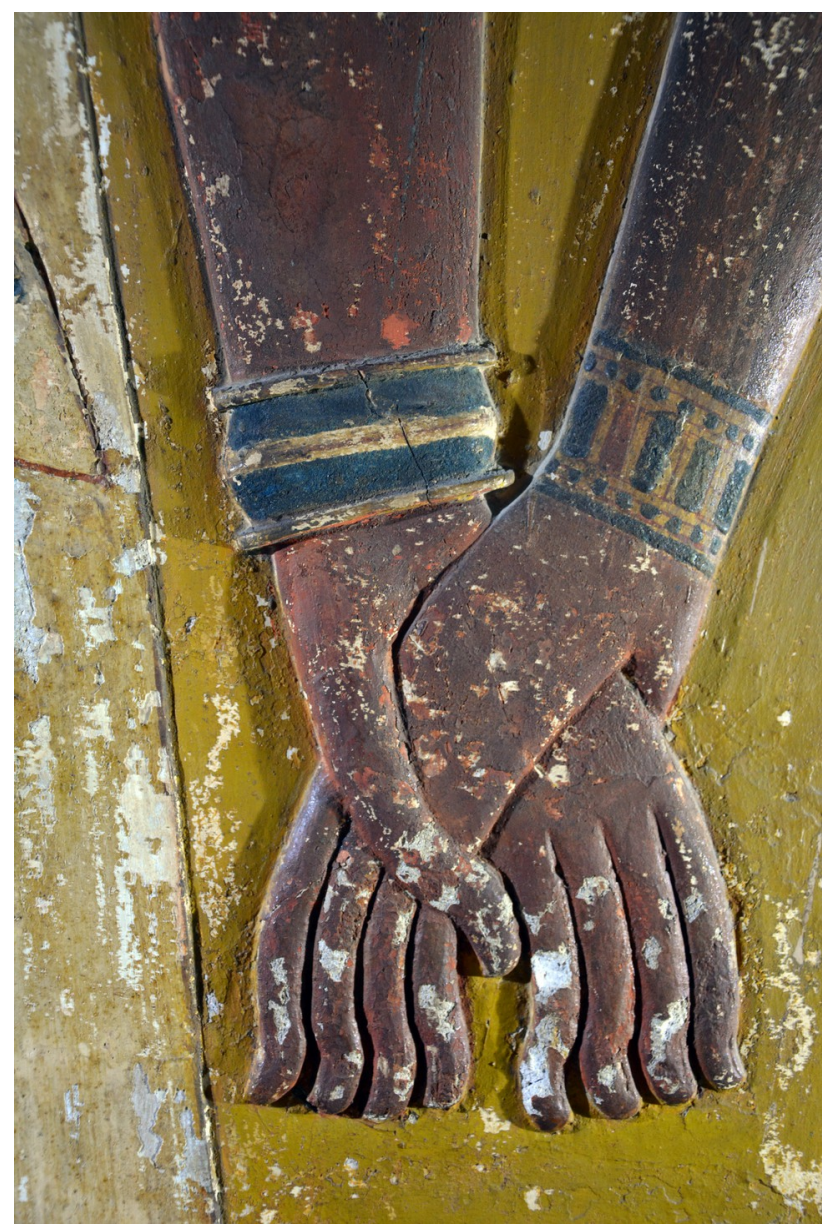

Figure 8 . HD photographic mapping of the surface.

To the main portions of carved limestone and tendentially homogeneous layers of color, are added the negative units of cracks and failures. Among the latter, the most widespread are the gaps of color, divided into two categories: loss of the painting layer or loss of the deeper and thicker preparatory layer. In another group have been included the gaps which have been covered by a subsequent layer of color. Finally the layers in detaching have been mapped, together with surface deposits (dirt) and mixture integrations (Figure 9).
Each area was investigated with imaging techniques in order to shed light on the distribution of original and modern materials on the polychrome surface and were also used for a preliminary investigation to select measurement spots for spectroscopic analyses. In particular, Visible Induced Luminescence (VIL) is a photographic technique allowing the spatial distribution of Egyptian blue, even if present as residuals and hardly visible to the naked eye. The ultraviolet-induced visible fluorescence (UVf) photography is based on capturing visible light emitted by the materials after irradiation with ultraviolet light. UV fluorescence photography may reveal the distribution of organic materials (i.e. binders, consolidants, varnishes etc.) often allowing to identify retouchings and over-paintings. This simple but powerful technique has some constrains in order to acquire good images. Among a special setting is necessary: the fluorescence emission images must be acquired in a total dark room in order to limit the influence of stray light. In the museum was not possible to reach this condition, and only few images were acquired in the lower part, thanks to an improvised coverage. The identification of pigments was performed by means of portable techniques such as X-ray Fluorescence (XRF), Fiber Optic Reflectance Spectroscopy (FORS) and in few areas, by Total Reflectance FTIR Spectroscopy (TR-FTIR). FORS provides molecular data useful for the identification of pigments and colorants and it is regularly performed together with the XRF technique, that reveals the elemental composition of the analyzed materials.
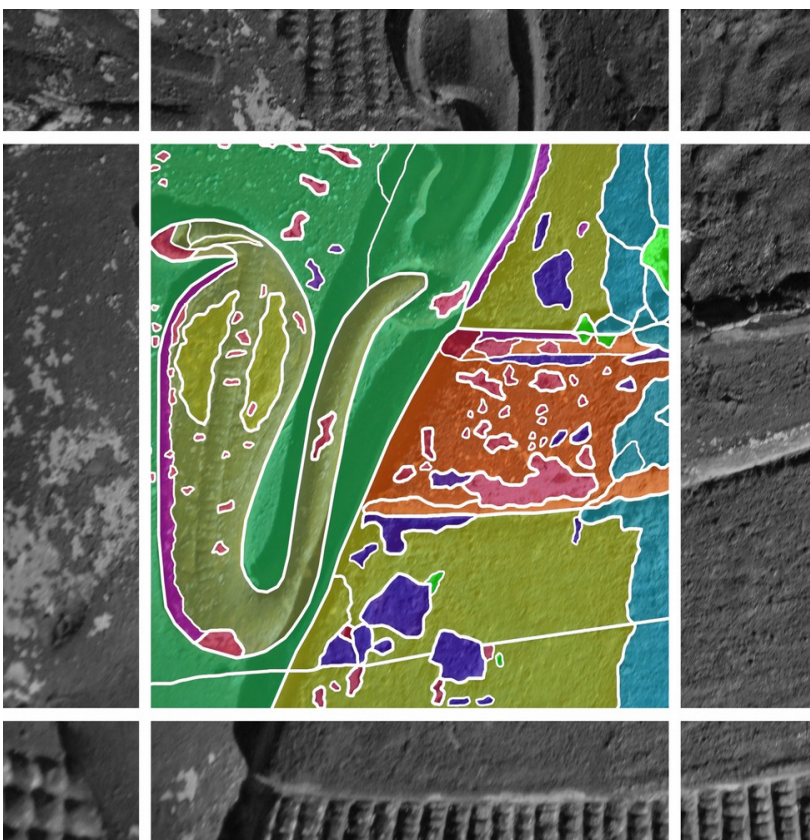

Figure 9. Stratigraphic mapping of the main homogeneous portions on the sample I17. 


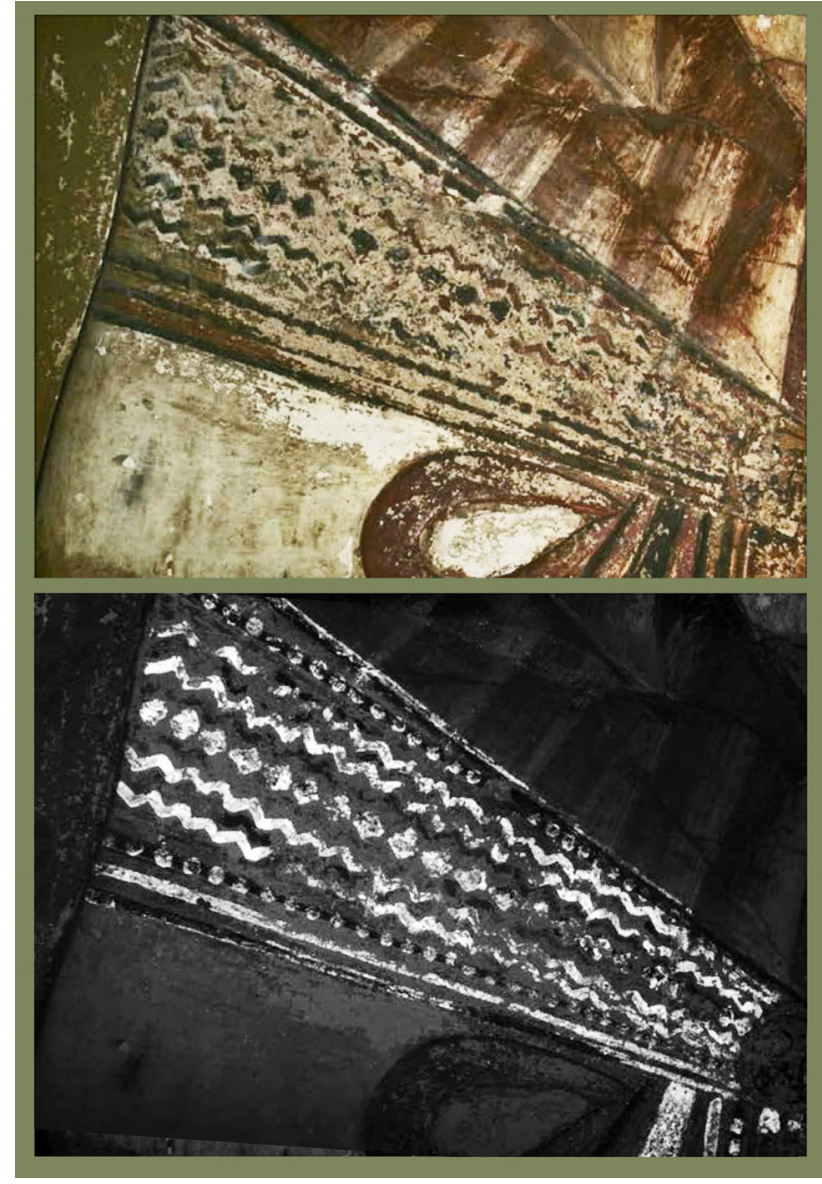

Figure 10. Visible and VIL images of Seti I's belt, showing the presence of a scheme painted with Egyptian blue (white in the VIL image below).

\subsection{The first results}

Preliminary results allowed us to focus some passages of the history of this fragment, from its realization to the present. The digital documentation of the object has created an excellent support for the mapping and management of the collected information (conducted surveys, results, stratigraphy, fragments identification, etc.). A first aspect of the preliminary stratigraphic survey by samples is the documentation of all traces of loss or removal of material, along with the identification of the visible contours of fragments extracted from the tomb and reassembled in Florence. The 3D survey of detail allowed the appropriate placing of the optical microscopy spot insights, focusing on the most important points for further investigation.

Even if still on a preliminary phase, this study shows how the combination of imaging and spectroscopic techniques allowed the characterization of many materials and the mapping of their distribution on the surface. Several pigments of the original painting layer have been identified as well as many anomalies due to subsequent interventions. 35 areas were investigated through VIL images, providing an essential tool for the identification and mapping of the original Egyptian blue on the surfaces of the basrelief. The comparison of visible and VIL images revealed the presence of the blue pigment in several areas. An example is shown in Figure 10. The Egyptian blue it is used for the decorations of the clothes, the jewels and the hairs of Hathor. In the upper part of the jamb only traces of Egyptian blue have been detected and these latter appeared to be covered by other pigments. About 50 areas were analyzed by non-invasive techniques avoiding any sampling and allowing the identification of many materials on the surface. Spectroscopic analysis were focused on areas characterized by a VIL positive response, and, as expected the XRF investigations revealed the presence of copper $(\mathrm{Cu})$, but only by FORS technique it was possible to identify unambiguously the Egyptian blue pigment (Figure 11). We must say that all the blue areas are always indicated in the drawing documentation made by Rosellini's expedition. This seems to confirm the correctness of his collaborators work.

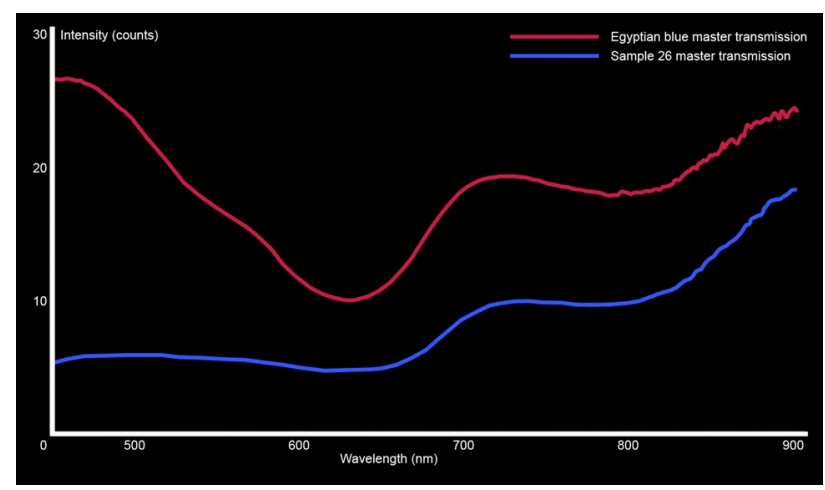

Figure 11. FORS spectrum of the area on the Hathor blue hairs of (SETI_26 blue line) compared with a reference standard.

All the XRF spectra acquired, especially those on the gaps, showed the peak of calcium $(\mathrm{Ca})$ and sulphur $(\mathrm{S})$, probably related to calcium sulphate $(\mathrm{CaSO} 4$ or gypsum $\mathrm{CaSO} 4 \cdot 2 \mathrm{H} 2 \mathrm{O})$. This seems to confirm the highly probable presence of a gypsum based preparatory layer between the limestone and the painting layers. This hypothesis has to be confirmed by other non-invasive techniques or better, through the examination of micro-samples. Iron $(\mathrm{Fe})$ and strontium (Sr) signals were also observed in all the areas, probably due to common impurities in the ground layer. Red areas appeared to be painted with red ochres (Fe2O3) together with a low amount of cinnabar $(\mathrm{HgS})$ while yellow areas are probably painted with orpiment (As2S3) as suggested by XRF spectra, showing the presence of arsenic (As). This element is frequently detected on the surfaces of this bas-relief, even on areas of different colours, such as black or blue. This presence must be examined in depth in order to explain its presence all over the surfaces. The presence of pigments or in general materials, not compatible with those traditionally employed on these artifacts was detected, as cobalt $(\mathrm{Co})$, barium $(\mathrm{Ba})$ and zinc $(\mathrm{Zn})$. This materials are mainly located on the upper part of the basrelief, that appears strongly repainted. An example is represented by the rectangular elements inserted on the frame and the starry sky. As already described, only few areas were investigated with UVf. Notwithstanding this, the few photos are extremely interesting allowing to highlight the presence of materials not pertaining to the original pictorial surface (Figure 12).

\section{CONCLUSIONS AND PERSPECTIVES}

The implementation of the digital documentation could provide a useful 3D model for the interactive mapping of the increasing results. The first next step may be a very high defined digital acquisition. Geophysical survey may confirm the shape and size of the fragments, their articulation and the presence of iron clamps. The investigated fragment of KV17 is the result of 
several repaintings, retouches and protective treatments. The diagnostic essay performed and the preliminary results obtained proved that the combination of the imaging techniques together with elemental and molecular spectroscopies is a powerful tool for the knowledge of the materials. Its high potential open many research directions. On one hand the need of an extended study of the relief is evident, on the other hand many aspects were highlighted that deserve to be further investigated. A complete UVf examination would allow to better highlight the areas subjected to overpainting or retouches. In addition, the findings obtained till now, would address a new and more representative essay by punctual analysis. However, in few and limited areas, a micro-sampling could be considered as an additional and strategic tool to implement the material knowledge of this artifact. The analysis of the traces could be extended to working traces or overlapping layers. Ordered in chronological sequences, they will allow a better identification of some phases of the life cycle of this object, before and after its discovery, inside and out of the tomb. A monitoring campaign of some environmental parameters began, to verify the general conservation conditions. It could provide risk levels by more accurate data on the nature and stability of degenerative phenomena and their evolution speed. In the perspective of contributing to the knowledge of the original building, the study could be developed in comparison with the relief exhibited at the Louvre Museum. Similarities and differences between the two reliefs could be highlighted, due to the phases and the modes of realization (teams of decorators) or subsequent transformations. Investigations could increase scientific cooperation projects between institutions which keep other detached fragments from the tomb of Seti I.

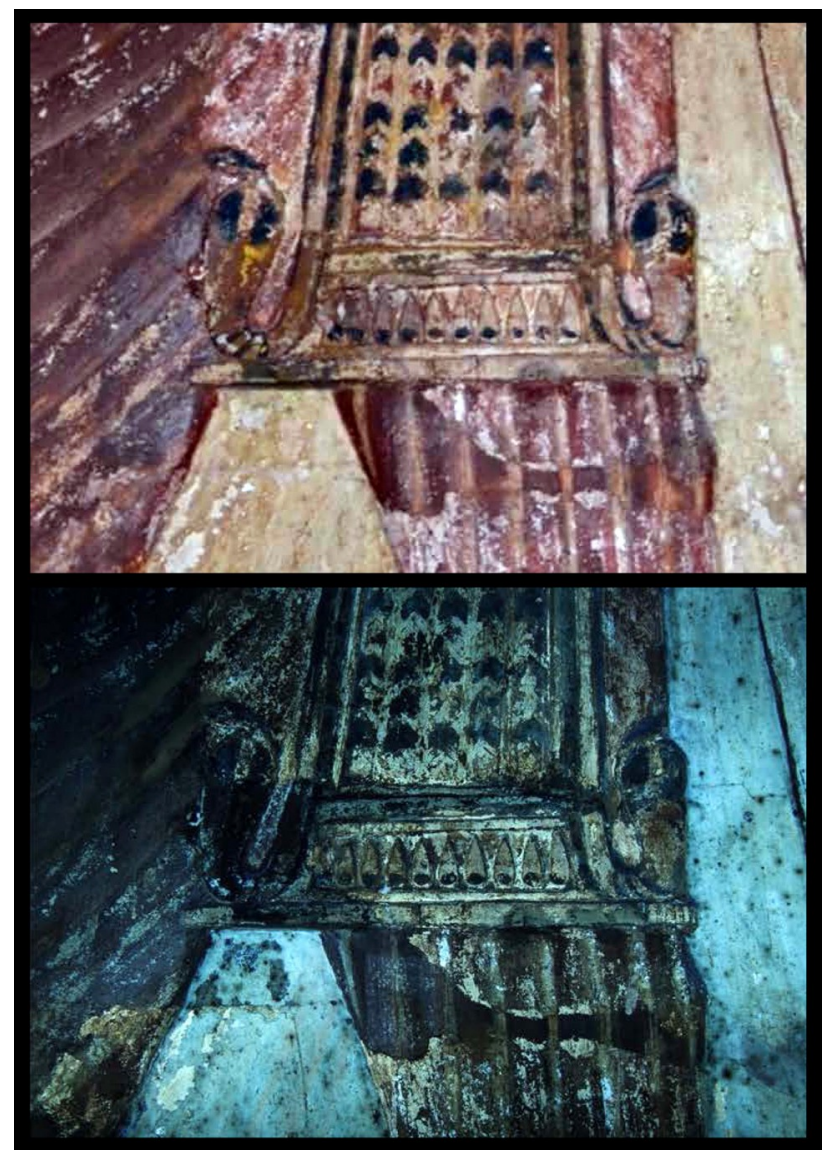

Figure 12. Visible and Uvf images of the integrated area on the skirt of Sethi I. the repainted area is clearly distinguishable.

\section{ACKNOWLEDGEMENTS}

Special acknowledgements must be paid to the Florence Archaeological Museum, especially in the person of M. Cristina Guidotti, Director of the Egyptian Section, for supporting the project with a longlasting view and perspective. We also thank the RAM restoration enterprise for providing tools and products, essential for the first development of the study.

\section{REFERENCES}

Bacci, M., 2000, UV-Vis-NIR, FT-IR and FORS spectroscopies. Modern Analytical Methods. In Art and Archaeology, Chemical Analysis Series, 155, John Wiley Sons, pp. 321-362.

Belzoni G. B., 1820, Narrative of the operations and recent discoveries in Egypt and Nubia, Murray, London.

Carter, H., 1905, Report of Work Done in Upper Egypt, 19031904. In Annales du Service des antiquités de l'Égypte, 6, pp. 112-129.

Casini, A., Lotti, F., Picollo, M., Stefani, L. \& Buzzegoli, E., 1999, Image spectroscopy mapping technique for non-invasive analysis of paintings. Studies in Conservation 44, pp. 39-48.

Donadoni, S., 1965, La decorazione della tomba di Seti I nella Valle dei Re, Fabbri editore, Milano.

Gabrieli G., 1925, L'egittologo Ippolito Rosellini e le sue lettere dall'Egitto (1828-1829), Befani, Roma.

Gamurrini G. F., 1873, Relazione storica del R. Museo Egizio ed Etrusco in Firenze, Cellini, Firenze.

Hartleben H. (ed.), 1909, Lettres et journaux de Champollion recueillis et annotés par H. Hartleben. Tome deuxième. Lettres et Journaux écrits pendant le voyage en Egypte, Ernest Leroux, Paris.

Hornung, E., 1991, The Tomb of Pharaoh Seti I, Artemis, Zurich.

Hornung, E., 2001, The tomb of Seti I. In The treasures of the Valley of the Kings: tombs and temples of the Theban West bank at Luxor, Weeks, K. R. (ed.), American University in Cairo Press, Cairo, pp. 194-211.

Jones, M., 2003, The work of the American Research Centre in Egypt in the Tomb of Seti I in the Valley of the Kings, 19981999. In Egyptology at the dawn of the twenty-First Century: proceedings of the Eighth International Congress of Egyptologists, Cairo 2000, Hawass, Z. (ed.), American University in Cairo Press, Cairo, pp. 252-261.

Lefèbvre, G., 1886, Les hypogées royaux de Thèbes, première division: Le tombeau de Séti Ier. Memoires publiés par les membres de la Mission archéologique française au Caire II. Ernest Leroux, Paris.

Mc Glinchey, C., 2012, Handheld XRF for the examination of paintings: proper use and limitation. In Art and Archaeology, Studies in Archaeological Sciences series, Shugar, A. N., Mass, J. L. (eds.), Leuven University Press, Leuven, Ch. 4, pp. 131-158. 
Milani, L. A., 1923, Il regio Museo Archeologico di Firenze. Sua storia e guida illustrata, Seeber, Firenze.

Reeves, N., Wilkinson, R. H., 1996, The Complete Valley of the Kings: Tombs and Treasures of Egypt's Greatest Pharaohs. Thames \& Hudson, London, pp. 137-139.

Rorimer, J. J., 1931, Ultraviolet Rays and their Use in the Examination of Works of Art, Metropolitan Museum of Art, New York.

Rosellini, I., 1830, Breve notizia degli oggetti di antichità egiziane riportati dalla spedizione letteraria toscana in Egitto e in $\mathrm{Nu}$ bia eseguita negli anni 1828 e 1829 ed esposti al pubblico nell'Accademia delle arti e mestieri in S. Caterina, Piatti, Firenze.

Rosellini, I., 1834, I monumenti dell'Egitto e della Nubia. Parte seconda. Monumenti civili. Tomo 1, Niccolò Capurro, Pisa.

Rosellini, I., 1844, I monumenti dell'Egitto e della Nubia. Parte terza. Monumenti del culto, Niccolò Capurro, Pisa.

Schiaparelli, E., 1883, Guida del Museo Archeologico. I. Antichità egiziane, Bencini, Firenze-Roma.

Schiaparelli E., 1887, Museo archeologico di Firenze. Antichità egizie ordinate e descritte da Ernesto Schiaparelli. Parte pri$m a$, Tipografia della Regia Accademia dei Lincei, Roma. pp. 320-322.

Verri G., 2009, The spatial characterization of Egyptian blue, Han blue and Han purple by photo-induced luminescence digital imaging. Analytical and Bioanalytical Chemistry, 394(4), pp. 1011-1021.

Weeks, K. R. (ed.), 2000, Atlas of the Valley of the Kings. Publications of the Theban Mapping Project 1, American University in Cairo Press, Cairo, sheets 34-36. 